Historic, Archive Document

Do not assume content reflects current scientific knowledge, policies, or practices. 



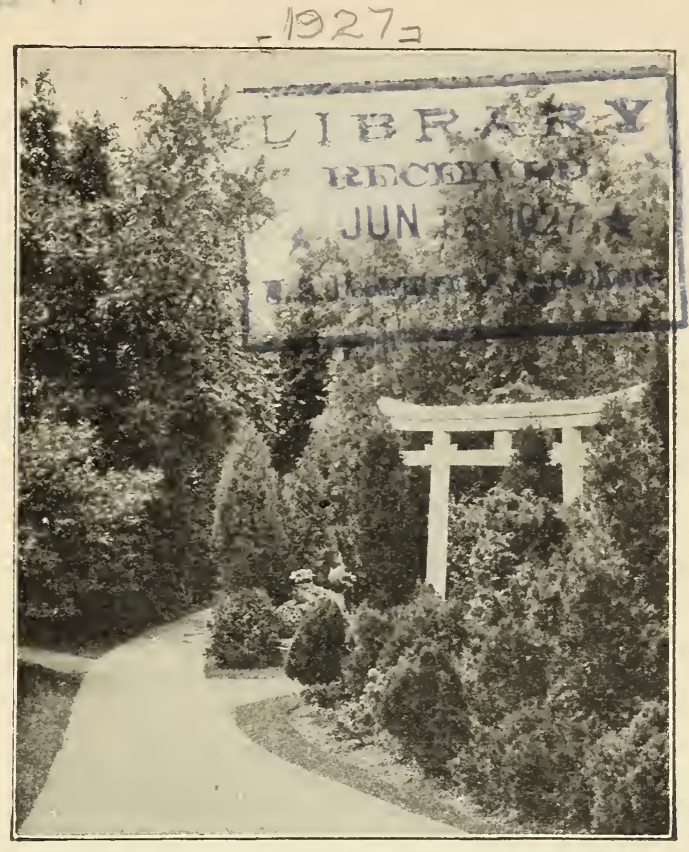

\section{Our Condensed Nursery Catalog}

THIS is not a complete list of the stock we grow and sell, but it covers the principal items; so, if you do not see what you want, be like the boy, "call for it."

Nothing in this list is new or untried. Each item offered has been in cultivation in different localities for many years and has proven entirely hardy and reliable.

If you pay your money for low-quality stock, you will get just that, and you will not get the results from it that you should.

Invest in good trees and plants, and reap the biggest returns possible on your investment.

WE SELL A HALF DOZEN AT DOZEN RATES.

The Denver Nursery and Landscape Company

4226 Zuni Street, Denver, Colorado 


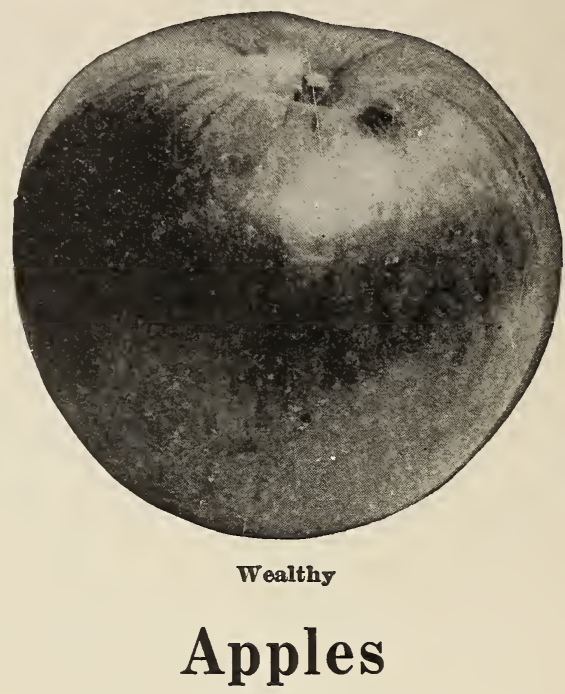

Price 5 to 7 feet.

Each, 85c; Per Doz. $\$ 9.00$ Price 4 to 6 feet

Each, 85c; Per Doz. $\$ 9.00$
Each, 75c; Per Doz. 7.50

Taking into consideration its hardiness, productiveness and general commercial value, the apple stands at the head of the list of fruits. In selecting the most important varieties for cultivation, it has been our constant aim to secure only those of standard excellence, and in no instance to recommend a novelty without ascertaining its history from a reliable source.

\section{SUMMER VARIETIES}

DUCHESS OF OLDENBURG-A large beautiful apple. roundish. Streaked red and yellow. Tender, juicy and pleasant. Tree a vigorous, fine grower and abundant bearer. Very hardy. September.

DYER-Color a light clear yellow, tender, juicy, and pleasant, one of the best eating apples; begins ripening in August and ripens continuously for six weeks. Tree a good grower.

IIVELAND (Liveland Raspberry)-Color orange yellow, striped, splashed and shaded with red, showing gray dots through the color, flesh light yellow, often stained with red; fine, tender, juicy; core medium open; flavor subacid, good.

RED ASTRACHAN-Tree vigorous, upright, hardy and productive. Fruit medium to large; surface smooth, marbled and striped on greenish yellow; flavor acid.

RED JUNE-Medium. red; juicy, good flavor. Abundant bearer. Last of June.

YELLO iv TRANSPARENT-A Russian apple. Tree is a hardy, upright grower; regular and early bearer, medium size. Color a rich, transparent yellow with a faint blush on sunny side; flesh melting, juicy, sub-acid.

\section{AUTUMN VARIETIES}

FAMEUSE (Snow)-Medium size, roundish; crimson, sometimes striped in northern localities. Flesh snowy white; very tender, fine, juicy, mild, sub-acid; one of the finest dessert fruits. Hardy and prolific. Very popular. October and December.

MAIDEN BLUSH-Large, smooth, regular, evenly shaded red cheek or blush on a pale yellow ground; flesh white, tender, sprightly, with a pleasant sub-acid flavor bears large crops; free. August to October.

RAMSDELL'S SWEET-Rather large, oblong dark red, best fall sweet apple, sometimes called English Sweet. October to December.

CHENANGO (Strawberry)-Rather large, oblong, conical, angular; whitish-yellow, striped and splashed with light crimson; flesh white, very tender, with mild, pleas ant sub-acid flavor. A market and eating variety. Tree vigorous and productive.

WEALTHY-Origin, Minnesota. Large, round; red; very handsome; fine quality; good grower. Perfectly hardy and most reliable. Very popular throughout the north. Long keeper in cold storage. October to January. 


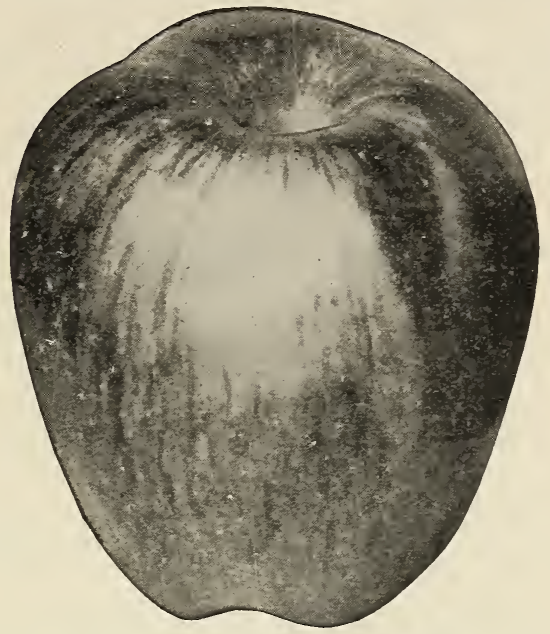

Delicious

\section{WINTER VARIETIES}

BEN DAVIS-Tree thrifty, upright grower of almost perfect shape. Fruit large, round, sometimes variable in form; surface smooth often polished yellow, covered and splashed bright red; flesh white, tender, juicy; flavor subacid, not rich quality; only good for market and cooking. November to Spring.

DELICIOUS-Flourishes well in every state of the Union. Bears annually; great yielder; hangs well on trees. Trees very thrifty, long lived and extremely hardy. Fruit very large, nearly covered with brilliant, dark red; flesh fine grained, crisp, juicy, melting and delicious ; splendid keeper and shipper; should be in every orchard.

GANO-Fruit is bright red on yellow ground, with no stripes; large, oblong, surface smooth, polished; dots minute; basin shallow, sometimes deep; eye large, cavity deep; brown in color; stem medium to long; core medium. Tree healthy, vigorous and prolific bearer. January to April.

GRIMES GOLDEN-This is one of the most popular apples in cultivation. Tree strong, thrifty grower. Fruit medium or above, cylindrical; regular surface, yellow veined, russeted; flesh yellow, firm, very fine grained, juicy : flavor sub-acid; quality rich. For dessert, cooking and market. November and December.

JONATHAN-Tree of rather slender growth and spreading habit; fruit medium or above in size, round or oblong; surface very smooth, waxy yellow, often wholly covered with brilliant red; flesh whitish yellow, tender, very juicy for dessert and cooking; quality best. October to February.

NORTHWESTERN GREENING-Fruit medium to large, averaging from seven to eight ounces each and very uniform in size. Color greenish yellow, flesh juicy, firm and fine grained. Very fine quality and flavor. Tree is very hardy and a thrifty grower, an early and continuous bearer. One of the longest keepers. January to Spring.

INGRAM-A fine little apple, of the highest quality, seedling of the Rawles Janet which it surpasses in size and value, one of the earliest and heaviest bearers, adapted to this section. Fine quality, tree hardy. December to May.

RAWLES JANET-Tree good grower, not so large as some; fruit medium; somewhat conical, regular; surface smooth, mixed and striped on yellow and green; flesh yellowish, crisp, fine grained, juicy; flavor sub-acid; quality good to very good. For desert, kitchen, market and cider. November to Spring.

TALMAN SWEET-Medium size, pale yellow, slightly tinged with red; firm, rich and sweet; excellent for preserving; tree vigorous, very hardy and productive. November to April.

WINESAP (Stayman's)-Large, roundish, deep red; medium quality ; keeps well; tree a fair grower and good bearer. December to May. 
WINTER BANANA-A highly prized and valuable market sort. Beautiful yellow fruit; flavor exquisite and very tempting; highest quality. Productive. Reliable growers represent it to be hardy North. Very popular for dessert.

YORI IMPERIAL-Tree moderate grower and productive, fruit large, lop-sided; surface smooth; color mixed bright red on yellow ground; flesh yellowish, tender, juicy, flavor mild sub-acid; quality very good; for market, table, kitchen. Norember till Spring.

\section{Crab Apples}

Price 5 to 7 feet

Price 4 to 6 feet.

Each, 85c; Per Doz. $\$ 9.00$ Each, 75e; Per Doz. 7.50

HYSLOP - Tree a moderate grower, making a beautiful shaped, thrifty tree; bears young; fruit large, nearly round, flattened at the ends; skin smooth, color dark rich red on yellow ground; flavor very good.

RED SIBERIAN-Large, round, brilliant red on a pale yellow ground; flesh acid and greatly esteemed for preserves and jellies.

TRANSCENDENT-A very strong grower, making a large, beautiful tree; an early and abundant bearer, fruit large, round, skin smooth, color rich yellow, shaded with red. August and September.

WHITNEY-Tree thrifty, upright grower; fruit large, skin smooth, striped and splashed with carmine; flesh firm, juicy, of pleasant flavor. One of the very best. August.

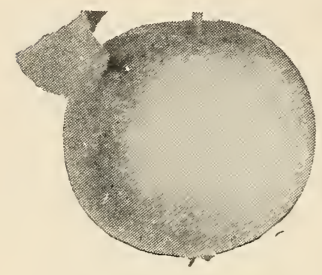

Whitney Crab

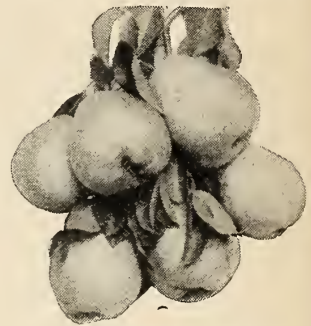

Duchess Pear

\section{Pears}

Pears succeed best on rather steep hillsides. Plant pears midway on the slope, putting something else on the upper and lower sections. Cultivate sparingly, so as to induce a very slow growth, and let blue grass take the land before the trees come into fruitage. When blight appears, cut off the affected parts at once and burn them; cut six inches below the lowest blight, to insure taking all infected sap.

\section{EARLY VARIETIES}

BARTLETT-Large size, with beautiful blush next to the sun; buttery, very juicy and high flavored; bears early. August and September.

Price 5 to 7 feet......Each, \$1.50; Per Doz. \$16.00 Price 4 to 6 feet............................Each, 1.25; Per Doz. 14.00

\section{AUTUMN VARIETIES}

DUCHESS D'ANGOULEME-Dwarf. Very large, oblong, obovate, dull greenish yellow, flesh white, very juicy, buttery, with a rich, excellent flavor. Tree a strong grower. October.

Price ..................................................Each, \$1.25; Per Doz. \$14.00

FLEMISH BEAUTY-Large, beautiful, juicy, melting, rich and fine; good bearer; one of the hardiest and does well nearly everywhere. September and October.

Price, 5 to 7 feet.................................Each, \$1.50; Per Doz. $\$ 16.00$ Price, 4 to 6 feet.

KIEFTER sun; juiey and melting. One of the best for canning and preserving; the most profitable to grow. Tree healthy, hardy and vigorous. Does not succeed on quince, therefore no dwarfs should be planted. Kieffer receives more praise and condemnation than any other. It is liable to overbear, therefore special pains should be taken to thin the fruit.

Price, 5 to 7 feet...........................Each, \$1.25; Per Doz. \$14.00 Price, 4 to 6 feet................................. $\$ 1.00 ;$ Per Doz. 11.00 
In order to renew our pleasant relations with old customers and encourage new ones, we are offering the following Club Orders:

\section{CLUB ORDER \#1}

\section{Yellow Transparent Apple $3^{\prime}-4^{\prime}$}

1 Wealthy Apple $\quad 3^{\prime}-4^{\prime}$

1 Early Richmond Cherry $3^{\prime}-4^{\prime}$

2 Concord Grapes

2 Goose Berries

1 Crimson Rambler

1 Dorothy Perkins

2 Bridal Wreaths 12"-18"
CLUB ORDER \#2 -. \$5.00

Includes order \#I, and

1. Anchusa Italica

2 Iilies of the Valley

I Paniculata Graniflora

1 White Peony

1 Red Peony

1 Columbine

2 Sedum

On account of the low prices quoted we can make no changes in these Club Orders. They will be sent exactly as quoted, express prepaid to your station.

A small climbing rose will be given free to anyone who sends in the names of five prospective buyers.

Information Bureau always open - any and all questions promptly and cheerfully answered. Write us for suggestions and estimates on Park, Home and Orchard Planting.

Over thirty-five years of successful business in and near Denver is your guarantee of our responsibility. Our facilities for handling your orders are bigger and better than ever. Only first class stock carried.

The Denver Nursery and Landscape Company Office - 4226 Zuni Street Denver, Colorado 


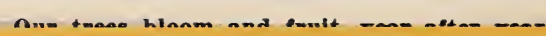




\section{Plums}

The plum delights in a cool, not too dry situation, and good rich soil. Plant trees 10 to 15 feet apart, in rows. The varieties we offer have been thoroughly tested, and are standbys. These may be relied upon to furnish crops of this profitable and delicious fruit.

Price, 5 to 7 feet................................each, \$1.25; Per Doz. \$14.00 Price, 4 to 6 feet..............................Each, 1.00; Per Doz. 11.00

\section{EUROPEAN VARIETIES}

GREEN GAGE (France)-Medium; greenish-yellow ; semi-cling; flesh juicy, rich and delicious; one of the best for dessert. Tree slow grower. September.

LOMBARD-Tree vigorous, hardy and productive; fruit of mediuin size, roundish oval, slightly flattened at the ends; skin of a delicate violet-red, paler in shade; flesh deep yellow, juicy and pleasant. August.

SHROPSHIRE DAMSON-A plum of fine quality. The flesh is amber colored, juicy and sprightly. Very productive and a valuable market variety. Freestone. September.

\section{NATIVE VARIETIES}

COMPASS CHERRY-Small, purplish red, with large pit, flesh yellow and very good for cooking. The original cross of Miner Plum and Sand Cherry.

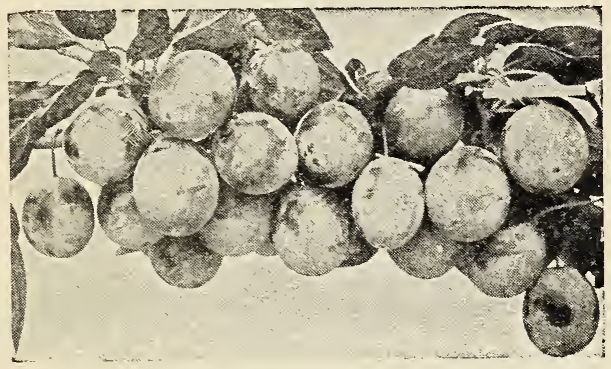

Terry Plums

DE SOTO-Resembles Miner in form and color, but two weeks earlier. Fine for eating or canning. Tree a moderate grower; bears young and profusely; hardy north. Is best planted on moist rich ground and the fruit thinned. Use this variety for fertilizing.

TERRY-One of the largest and handsomest native plums yet produced; color clear, red, flesh juicy, fine quality. August. Tree vigorous and hardy.

WILD GOOSE-The most popular fruit with some fruit growers. Tree a vigorous, upright grower; fruit medium to large, rich golden yellow, shaded with red; flesh yellow and juicy; flavor rich and good.

WOLF-Fruit large, a perfect freestone. As to quality we find them superb for cooking and for serving with sugar as we use peaches. Tree a good grower; hardy. August.

WYANT-Large, round, oblong, dark red; flesh firm: freestone, and of excellent quality. Native of Iowa and hardy.

\section{JAPAN VARIETIES-Not Hardy}

ABUNDANCE-Large, roundish ; freestone; amber, turning to a rich cherry color with a whitish bloom; flesh light yellow, juicy, tender, sweet and excellent, vigorous and very productive. August.

BURBANK-Large, nearly globular; clear cherry red with thin lilac bloom; flesh deep yellow; rich, very sweet, with peculiar and agreeable flavor. Vigorous and a very zarly bearer. Last of August.

\section{HYBRID VARIETIES}

HANSKA-Beautiful color, bright red, with heavy bloom; flesh firm, yellow and of good quality; fragrant; apricot flavor; tree tall, rapid grower; pit small.

OPATA-Flesh firm, greenish with pleasant flavor. Pit small; season early; is strong grower and heavy bearer.

SAPA-Much like Oxheart cherry, dark flesh and juice. Fine quality. Five-foot trees at three years bear 1 to $11 / 2$ bushels and keep it up. Every home in the country should possess from one to a dozen of these wonderful trees. 


\section{Cherries}

Price, 5 to 7 feet ...........................Each, \$1.25; Per Doz. $\$ 14.00$ Price, 4 to 6 feet.................................... 1.00; Per Doz. 11.00 Cherry culture has been a success when proper attention has been given to the selection of varieties and their culture. The hardy, thrifty varieties of the Morello type may be freely planted with confidence of profitable results. The cherry tree should be planted in a naturally dry soil or the soil should be well drained, so that water may not remain near the roots for any considerable time.

DUKE AND MORELLO (Sour)

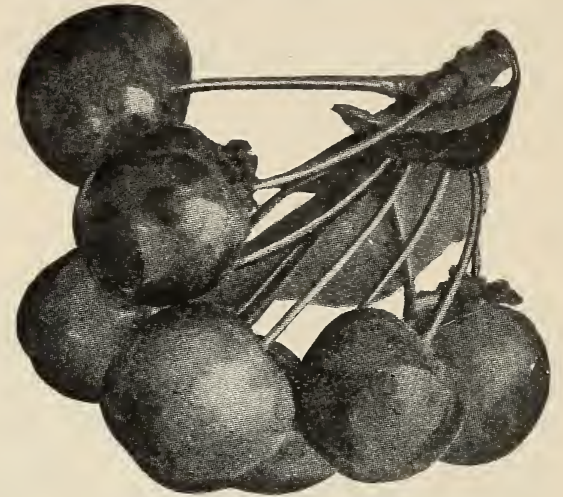

Early Richmond Cherry

EARLY RICIIMOND-Everywhere the most popular. Tree strong, thrifty grower, making a large, symmetrical head ; fruit medium size, dark red, melting, juicy; sprightly acid flavor and especially valuable for cooking purposes; tree an early and abundant bearer. Season last of May and first of June.

ENGLISH MORELLO-Tree moderate grower, hardy ; an early and great bearer; the most valuable of the late varieties. Fruit large, round; skin dark red, becoming nearly black when fully ripe; flesh dark red, tender, juicy and of a pleasant sub-acid flavor when fully ripe. July.

LARGE MONTMORENCY -A fine, large, light red cherry of the Richmond class, but larger and more solid; a more upright grower, equally hardy and productive. Second only to Early Richmond in value. Ripens ten days later.

WRAGG-Originated in Iowa. Medium to large in size long stem, dark purple when fully ripe. A variety well adapted for the prairie regions of the Northwest. Appears identical in tree and fruit with English Morello, but is claimed to be a new variety. Valuable late cherry. July.

\section{Peaches}

Price, 5 to 7 feet........................Each, 75c: Per Doz. \$8.00

Peach trees should be planted 16 to 18 feet apart. Cut weak shoots back about one-half and strong ones about one-third, but see that there is left a sufficient supply of fruit buds. Sickly and superfluous shoots should be cut out clean. The fruit is borne on wood of last season's growth, hence the necessity of keeping up a good supply of vigorous annual shoots all over the tree. Young trees should be well mulched every spring.

BOKHARA (F).-Raised from seed procured in Bokhara, Asia. It has been fruited in the Northwest for years and found to be one of the hardiest peaches known there. Tree has stood 28 degrees below zero with but little injury to the tips, and produced fair crops. Fruit, large, yellow, with red cheek, of good quality, perfect freestone; skin tough, a fine shipper. August.

CHAMPION (F.)-The earliest freestone and a firstclass shipper. Bears full crops when others fail. In comparison with the bountiful yield of all of the best kinds, it is of all of them the champion. Size large, flavor delicious, juicy, sweet, rich, excelling all other varieties; very handsome in appearance, creamy white with red cheek; very hardy; season earliest.

ELBERTA (F).-Large, yellow with red cheek. Of excellent quality; flesh yellow and melting; freestone. The market peach of America. 


\section{Mulberries}

RUSSIAN-Good shade and ornamental tree, rapid grower, excellent wind and snow break; most valuable to supply the native birds, thus keeping them from the more precious fruits. Fruit of little value.

Price 5 to 7 feet. Each............................................................50

Price 4 to 5 feet. Each …...............................................................40

Price 2 to 3 feet

Price 18 to 2 t incthes.

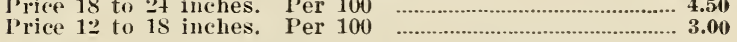

\section{Grapes}

Annual and careful pruning is essential to the production of good grapes. The roots cannot bring to maturity a fine crop of fruit if they are called upon to carry too much wood. Winter and early spring is the best time to prune, when the vines are dormant.

\section{RED VARIETIES}

Price, 2 year No. 1. Each............................40c; Ter Doz. $\$ 4.00$ AGAWAM-Bunch large, shouldered; berry large, reddish brown, tender vinous and of excellent flavor. Very vigorous and productive. Vine hardy and one of the best of its class.

BRIGHTON-Bunch large, shouldered; berries medium to large, round, dark red, tender, very little pulp, sweet, juicy, slightly aromatic and very good. Ripens early.

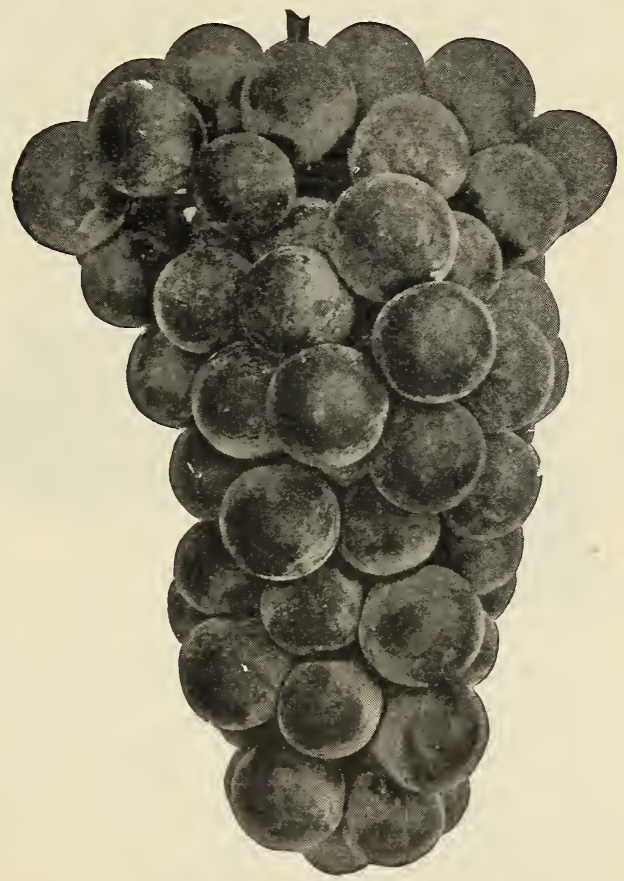

Concord Grapes

\section{BLACK VARIETIES}

CAMPBELL'S EARLY-A new, very large and fine early grape, black; strong, vigorous, hardy vine with thick, healthy leaves; clusters very large, usually shouldered, compact and handsome; berries large, nearly round, rich, sweet, very good; skin thin; seeds few and small, parting easily from the pulp; a good shipper. Ripens very early, but remains sound on the vines for many weeks. This makes it one of the most satisfactory and profitable market sorts to grow.

Price, 2 year, No. 1. Each. $.50 \mathrm{c} ;$ Per Doz. $\$ 5.00$ 
CONCORD-One of the most popular and reliable varieties we possess; bunch large, compact and shouldered: berry large, round, almost black with blue bloom, juicy, buttery and very sweet.

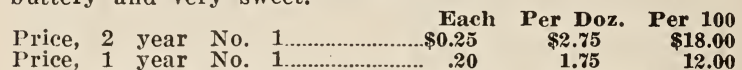

MOORE'S EARLY - A large grape, ripening three weeks earlier than Concord; good grower; berries large, good quality, and makes a moderate yield; very valuable as an early grape.

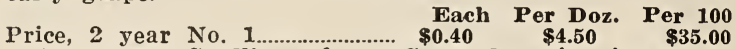

WORDEN-Seedling of the Concord, which it greatly resembles in appearance and flavor, but the berries are larger. The fruit is said to be better flavored and to ripen several days earlier. These qualities will give it the foremost rank among native grapes.

Price 2 year, No. 1. Each, 35c; Per Doz. \$3.50; Per $100 \$ 25$.

\section{WHITE VARIETIES}

NIAGARA-Occupies the same position among the white varieties as Concord among the black. Bunch and berries large, greenish white, changing to pale yellow when fully ripe. Skin thin but tough, quality much like the Concord. Price, 2-year. Each......................................40c; Per Doz. \$4.00 PockLINGTON-Seedling from the Concord. The vine is thoroughly hardy both in wood and foliage; it is a strong grower, never mildews in vine or foliage. The fruit is a light golden yellow, clear, juicy and sweet to the center, with little or no pulp; bunches very large, some times shouldered; berries round, very large and thickly set. Ripens with the Concord.

Price, 2 year No. 1. Each

40c; Per Doz. $\$ 4.00$

\section{Raspberries}

Plant two and a half feet apart in rows seven feet apart. Thin to four or five good canes in a hill; cut out old canes as soon as through fruiting.

\section{RED AND PURPLE CAP VARIETIES}

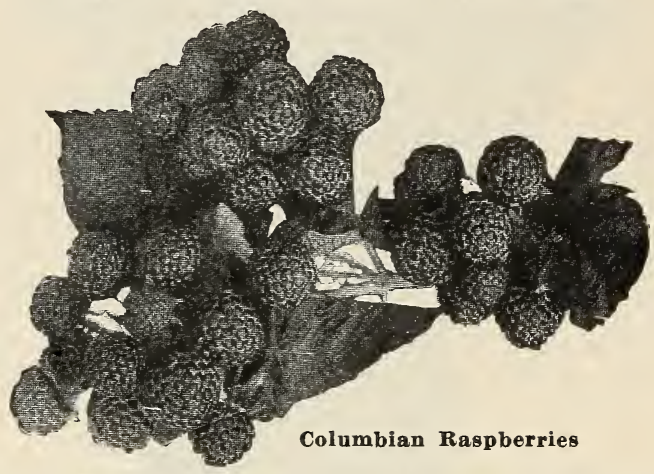

COLUMBIAN-The Columbian is a new variety of the Shaffer type of remarkable vigor and productiveness. Not very hardy and propagates from tips. Fruit very large, often an inch in diameter, shape somewhat conical, color dark red bordered on purple; adheres firmly to the stem and will dry on the bush if not picked: seeds small and deeply imbedded in a rich juicy pulp with a distinct flavor of its own. Succeeds wherever red sorts do well and promises to become the leading variety. A most delicious table berry.

Price 1 year.................................Per 25, \$2.25; Per 100, $\$ 8.00$ ST. REGIS EVERBEARING-The new everbearing variety. It gives a crop of fruit all summer and autumn fruiting on the old canes in generous quantities until late in August. By this date berries begin to ripen on the young canes and continue until late in autumn. Berries a re a bright crimson of large size and of surprising quality, sugary with full raspberry flavor. It succeeds upon all soils, whether light and sandy or cold heavy clay and the canes are absolutely hardy.

Price 1 year...........................................er 25, \$1.75; Per 100, \$7.00

BLACK VARIETIES

CUMBERLAND-Largest black raspberry knuwn; unusually strong grower, perfectly hardy. The most profitable raspberry grown.

Price, 1 year

.. Per $25, \$ 1.50$; Per $100, \$ 5.00$ 
GREGG-Extra big, enormously productive. Hardy ; firm black meaty berries. Late ripening and firm for shipping. Price, 1 year.............Per 25, \$1.50; Per 100, \$5.00

KANSAS-Originated at Lawrence, Kansas. Healthy, vigorous grower, early; berry is as large as Gregg and as good a shipper. Very productive, and valuable for early market. Price, 1 year................Per $25, \$ 1.50$; Per 100, $\$ 5.00$

\section{Blackberries}

Plant four feet apart in rows six feet apart. Pinch the canes back when four feet high. Light, moderately rich land is preferable.

Price........................................... 25er \$2.50; Per 100, \$9.06

MERSEKEAU-Renowned for hardiness of cane, great productiveness and large size berry. Is not "seedy" like many other sorts. Fruit jet black, and does not change color. Berries rich, melting and luscious, with little or no core.

SNYDER-The old standard. Very hardy, consequently much raised in cold climates. Berries medium size, juicy. ricb; strong, stout cane, thrifty growth and a very broad leaf.

\section{Currants}

Price Perfection, 2-year No, 1. Each 50c; Per Doz, \$5.00 Prices other varieties, 2-yr. No. 1. Each 30c; Per Doz. 3.00

The currant is one of the most valued of the small fruits. They mature Just before Raspberries and can be used either raw or cooked. Being very hardy, they do not winter-kill and are easy of cultivation, requiring little eare. They can be grown in any good garden soil.

WHITE GRAPE-Very large, yellowish white; sweet. or very mild acid; excellent for the table. The finest of the white sorts, very productive.

CHERRY-The largest of all red currants; berries sometimes more than one-half inch in diameter; bunches short; plant very vigorous and productive when grown on good soil and well cuitivated.

FAY'S PROLIFIC-For size, beauty and productiveness it is a remarkable red currant. The berry is equal to Cherry eurrant, while the Havor is superior. The stem is long. which permits rapid picking, valuable for both market and home. Fruit hangs on well, never dropplng, as in other currants.

PER FECTION-Bright red, and of a size larger than the Fay; size of berries is maintained to end of bunch. It is one of the most productive Currants. Rich, mild, sub-acid flavor and having plenty of pulp with few seeds. You can pick Perfections fast as cherries.

POMONA-This is one of the most profitable currants for the market: while not the largest in size, it outyields all other varieties. Color is a beautiful bright red, berry sweet and less acid than most of the general varieties, good size, and larger than Victoria; a vigorous grower with healthy, hardy foliage.

\section{Gooseberries}

DownING-Fruit very large, flesh whitish green, soft, juicy and good; plant vigorous and prolific; one of the best.

Price, 2-year ....................................Each, 35c; Per Doz. \$3.50

J OSSELYN (Red Jacket)-Large size, smooth, prolific and hardy. Has been tested by the side of all leading varieties, is freest from mildew of all. A wonderful cropper, with large, smooth, pale red fruit of first class flavor.

Price, 2-year old No. 1.........................each 50c Per Doz. $\$ 5.00$

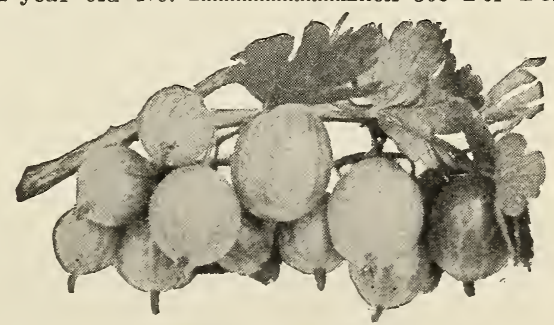

Josselyn Gooseberries

PEARL-A cross between Houghton and one of the large English varieties. It is very hardy and entirely free from mildew; superior in size and quality; as productive as Downing.

Price, 2-year No. 1

Each, 35c; Per Doz. $\$ 3.50$ 


\section{Strawberries}

\section{EVERBEARING VARIETIES}

PROGRESSIVE EVERBEARING-Very large, dark red and glossy; fine quality. It begins to bear in June with immense crops and continues until late in fall. It is one of the heaviest bearers of berries in June as well as a remarkable fall bearer. Will produce a fair crop of fruit the first summer.

Price

Per 100, $\$ 2.50$

\section{SPRING-BEARING VARIETIES}

SENATOR DUNLAP (S)-This berry is of the Warfield type, has a perfect blossom, is hardy, productive, a splendid keeper and able to hold its own under any "rough and tumble" methods of culture to which it is likely to be subjected. It is a very heavy bearer of good size, even fruit, of a very beautiful dark red color. It is a berry to grow for either home use or market.

Per 100, $\$ 1.25$

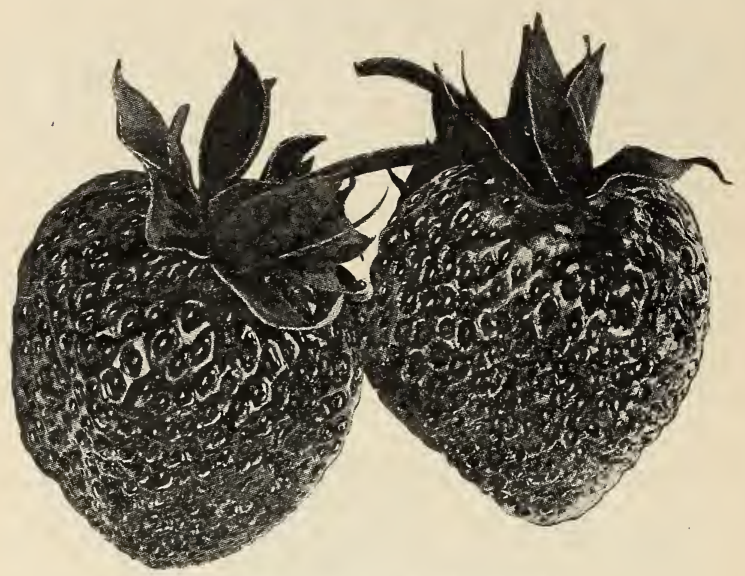

Senator Dunlap Strawberries

GANDY (S)-Large, light crimson; flesh of firm, good quality. Plants vigorous but should be planted in swamp or moist, clay soils. Perfect. Late.

GIBSON-This is the most popular strawberry extant today. Best for narket and best for the home garden. Berry large; dark glossy, red, nearly round, very productive. Plant Gibson and success will be yours.

Price .................................................................. 100, \$1.50

\section{Rhubarb}

This deserves to be ranked among the best early fruits in the garden. It affords the earliest material for pies and tarts, continues long in use, is valuable for canning. Use well grown roots, not divided old clumps.

WYATTS LINNEAUS-Large, early, tender and fine. Price Each 15c; Per Doz. \$1.50

\section{Asparagus}

The first garden vegetable of spring; it is a great delicacy and comes in just when it is most needed. One hundred roots will supply a small family and will last for years. Set the plants about eighteen inches apart in the row. Spread the roots out in the bottom of the hole or furrow and gradually fill in as the plant grows, so that the roots will be about four inches deep.

CONOVER'S COLOSSAI_Best for general planting.

Price …................................................................... 100, \$3.00 PALMETTO-Newer variety, earlier; probably as good. Price, ........................................................................ 100, \$3.00 
$\circ$

\section{Roses}

HYBRID PERPETUALS

ALFRED COLOMB-Bright carmine red; clear color, large, deeply built form; exceedingly fine.

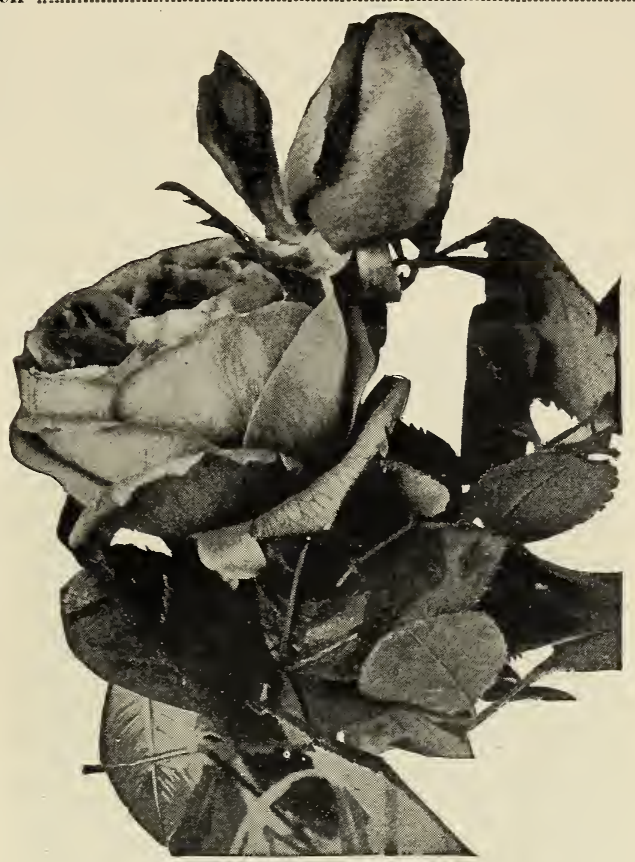

American Beauty Roses

AMERICAN BEAUTY-The world-famous rose. Rich, rosy-crimson, exquisitely shaded. Magnificent buds. Flowers extra large and deep petaled; of beautiful form and very double. This hardy rose has the ever-blooming qualities of the Tea Rose with the delicious odor of the La France. The great American forcer and bedder, each shoot producing a bud. A universal favorite. Not hardy.

Each

$\$ 1.00$

CLIO-A rose of perfect form and finish, with broad, thick petals, high full center, beautiful form pointed bud to fully opened flower. The color is a delicate satiny blush with slightly deeper center. The plant is vigorous and blooms freely, displaying its great flowers on good stems against large rich leaves.

Each

$85 \mathrm{c}$

FRAU KARI DRUSCHKI-Snow white, very large, perfect form. A vigorous grower and free bloomer. Bright,

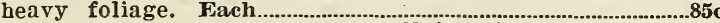

GENERAL JACQUEMINOT-This might be called the rose for the million, for it is still a universal favorite. Bright crimson scarlet, exceedingly rich and velvety. Each

MGNA CHARTA-Bright clear pink, flushed with vic let crimson; flowers large, fine form, sweet, very double and free bloomer.

Each

I SHA I P V W - New continues in bloom long after others are out of flower. Ea. 85c PRINCE CAMILLE DE ROHAN-Very dark, rich velvety crimson, passing to intense maroon, shaded black; large full flowers. One of the darkest roses and very

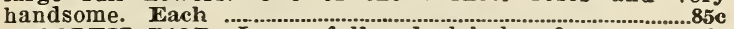

SOLEIL D'OR-Large, full and globular, fragrant, buds conical shaped; color varying from gold and orange yellow to reddish gold, shaded with nasturtium red.

Each $.85 \mathrm{c}$

ULRICH BRUNNER-An upright grower with bright healthy foliage. Flowers are a bright cherry red, good size and of fine form. Each. 


\section{CLIMBING ROSES}

CLIMBING AMERICAN BEAUTY-A strong, vigorous climber but may be kept pruned back to a large size bush rose. The blooms are the same size, color and fragrance as the old variety and when in bloom it is a perfect mass of color. Fach

$\$ 1.00$

CRIMSON RAMBLER-Nothing equals this as an all round hardy garden rose, on account of its brilliant color, profusion of bloom and length of time the flowers last. It may be used as a climber, or can be grown in large bush form. It blooms in large clusters of 50 to 100 flowers in a cluster, covering the foliage its entire length with a solid mass of the most beautiful, perfectly shaped miniature crimson blossoms. Blooms last of June and remains in flower longer than any other hardy out-door rose. Each

DOROTHY PERIN pink climbing rose. This new rose is of the same strong habit of growth as the Crimson Rambler, and the flowers are borne in clusters of thirty and forty and sometimes fifty to sixty. The flowers are large for a rose of this class. Very double and sweetly scented. Each..................75e

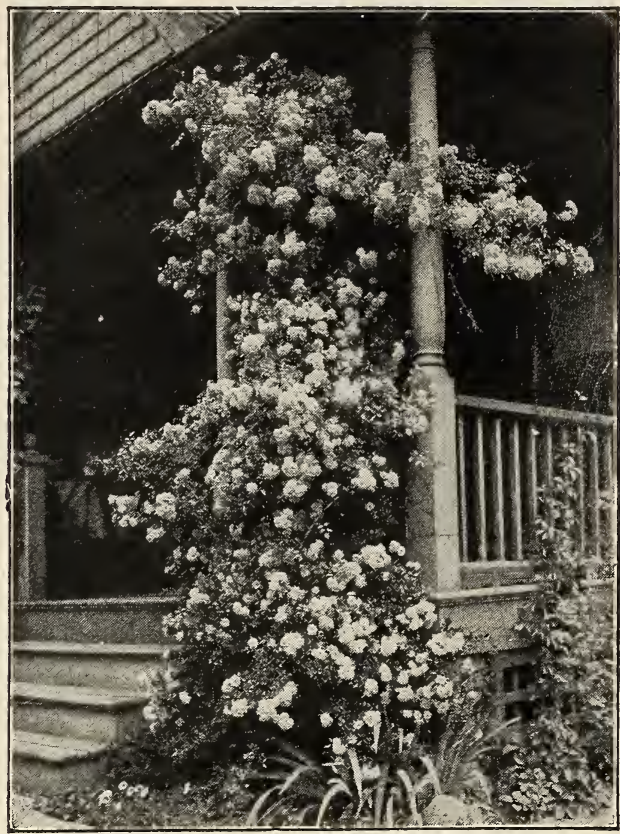

Crimson Rambler

FLOWER OF FAIRFIELD-A sort of the well-known and famous Crimson Rambler climbing rose. This new rose produces its lovely flowers until killing frosts stop further growth of the plant. The flowers are produced in great trusses, each carrying from thirty to forty blossoms of the brightest crimson, which remains undimmed to the end. Each QUEEN OF THE PRAIRIE-Bright rose in clusters, vigorous, very free bloomer. Each.......................................
SEVEN Sisters-Fine, free bloomer, bright scarlet: claimed by some to be hardier than Prairie Queen. Ea. 75c TAUSENDSCHON-Truly called "Thousand Beauties." One of the really reliable novelties. It bears its flowers in immense clusters; in color a soft pink when first opening, changing to a carmine-rose on the reverse as they expand. Each . $.75 \mathrm{c}$

\section{MISCELLANEOUS HARDY ROSES}

MAM PIANTIER-Flowers pure white of medium size; somewhat rosy in the bud form; produced in greatest abundance quite early in the season. The leaves are small; the bush hardy and spreading. Fine for masses, hedges, borders, cemeteries, etc. Each $.85 \mathrm{c}$

PERSIAN YELLOW-Similar to above, but with flowers fuller and of better form. Bright yellow; the most double of this class. The flnest hardy yellow rose. Each........\$1.00 
BABY RAMBLER ROSES

RED BABY RAMBLER-Crimson flowers. Very attrac. tire and popular. Each..............................................................85c

\section{MOSS ROSES}

CRESTED MOSS-The deep pink buds are surrounded with a mossy fringe and crest; fragrant. One of the best. Each .....................................................................................................85e

PERPETUAL WHITE-Pure white, blooms in clusters, double, beautiful, vigorous. Each...........................................85e

\section{Ornamental Shrubs}

The planting of ornamental shrubs is very largely on the increase, and this is as it should be, for with a good selection the lawn can always be beautiful. They are mostly of medium size, enabling one to plant a great variety on a small plat, and the wonderful assortment of foliage from the darkest green and purple to light orange and silver tints. This addition to the great variety in the blossoms, all unite to keep up a never failing interest. We have selected the very best for our climate.

FLOWERING SHRUBS-Variegated Colored FoliageBarberry, Golden Elder, Syringa, Variegated Weigelia.

Shrubs that Flower in May-Flowering Almonds, Honeysuckle, Japan Quince, Lilac, Snowballs, Spireas, Wisteria.

In Juno-Clematis, Deutzia, Elder, Honeysuckle, Peonies, Lilacs, Snowball, Spireas, Syringa, Weigelia, Wisteria. In July-Clematis, Spirea, Honeysuckle.

In August and September-Bignonia, Clematis, Honeysuckle, Hydrangea.

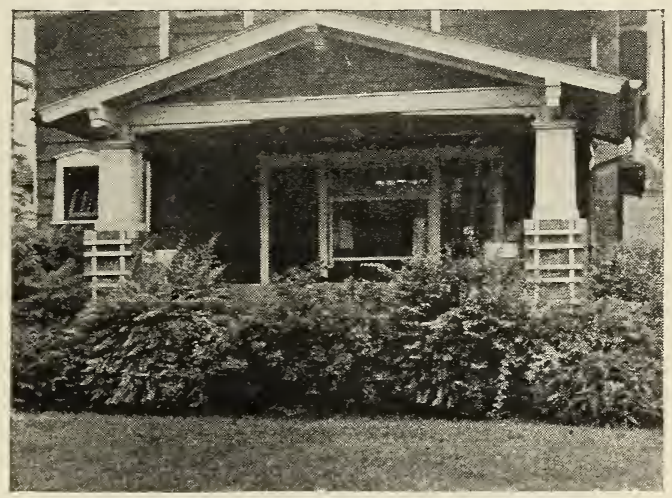

ALTHEA, or ROSE OF SHARON-Valuable because they bloom so profusely in late summer when other flowers are scarce. They form beautiful groups of hedges, their variety of colors making it possible to use quantities of them even in small grounds. 2 to $3 \mathrm{ft}$, each........75c

ALMOND, FLOWERING-Pink and white varieties. These beautiful shrubs are desirable and scarce. Hardy.

2 to 3 feet, each. . $.90 \mathrm{c}$

CALYCANTHUS (Carolina Allspice)-A well known native bush very double, purple fragrant flowers. Each, 90c.

CORNUS SIBERICA (Dogwood)-Grows 5 to 10 feet high, with clusters of fine, white flowers, succeeded by a fall crop of ornamental berries. Branches turn to bloodred during winter. 2 to 3 feet, each........................................75c

DEUTZIA (Pride of Rochester) - A very desirable shrub, of strong, hardy growth, bearing an abundance of beautiful racemes of purplish-white flowers. 2 to 3 feet.........75c

ELDER GOLDEN-The leaves are a bright and constant golden color; the flower cluster pure white. Valuable for contrasts and for massing. 2 to 3 feet, each...............75

FORSYTHIA-GOLDEN BELC-Pretty shrubs of medium size, blooming in spring before the leaves appear. Flowers are yellow, drooping, and are borne along the stem. They are exceptionally hardy and thrive in any locality. The green branches also add to their attractiveness and the graceful bush or pendulous habit. 2 to 3 feet, each........75c 
HONEYSUCRIE, UPRIGHT (White or Pink)-White or pink flowers which contrast beautifully with the foliage. Blossoms in June. 2 to 3 feet, each. ...75e

HYDRANGEA, ARBORESCENS STERILIS (also Hills of Snow, Summer Hydrangea, or Snowball Hydrangea.) The blooms are of the very largest size, of pure snowwhite color, and the foliage is finely finished. One of its most valuable characteristics is its coming into bloom just after the passing of all the early spring shrubs. 2 to 3 feet, each..................................................................................\$1.00

HYDRANGEA, PANICULATA GRANDIFLORA-These plants are absolutely hardy, grow in any soil and bloom the same year they are set out.They flower atuindantly, bearing hundreds of immense panicles of bloom. White turning to rose in autumn. An annual shortening of branches tends to increase the size of the flowers. Very fine and valuable for cemetery planting. 2 to $3 \mathbf{f t}$, ea. $\$ 1.00$

HYDRANGEA, Treo-The lovely Hydrangea Paniculata in tree form. These fine trees are three to four feet high, with strong, erect stems and splendid crowns, bearing great trusses of flowers. They are very effective for lawn; or if planted along the walk or driveway, they are wonderful when in bloom. By planting several of these beautiful trees you can prove to your friends that these Tree Hydrangeas are exceptionally nice and not commonly seen. Perfectly hardy here. Each .................................................\$2.00

LILAC (Common Purple)-Bluish purple flowers, well known. 2 to 3 feet, each...........................................................75e LILAC (Common White)-Cream white flowers.

Price, 2 to 3 feet. Each.................................................................75c

LILAC (Persian Purple)-Of more slender growth and finer foliage than the common lilac. Flowers purple in large, loose panicles. Price, 2 to 3 feet. Fach.................75e

PYRUS JAPONICA (Japan Quince)-The most beautiful of early blooming shrubs, and as a mass of scarlet or crimson, tinged in the exquisite green of its glossy foliage, it has no rival. 2 to 3 feet, each.........................75c

SNOWBALL (Common)-A popular shrub. Makes a large bush. Bears balls of pure white flowers in June. 2 to 3 feet, each..................................................................................75e

SPIREA (Thunbergii). The earliest of the Spireas to bloom. Of a rounded, graceful form. Branches slender and somewhat drooping. Foliage narrow and yellowish green, changing to delicate purple in fall. Flowers pure

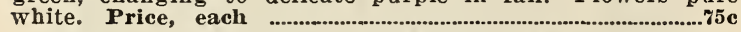

SPIREA, ANTHONY WATERER-A small dwarf variety $1 \frac{1}{2} \mathrm{ft}$. , covered with flat heads of pink flowers. Used for edging and in front of shrubbery. 12 to 18 in.............75e

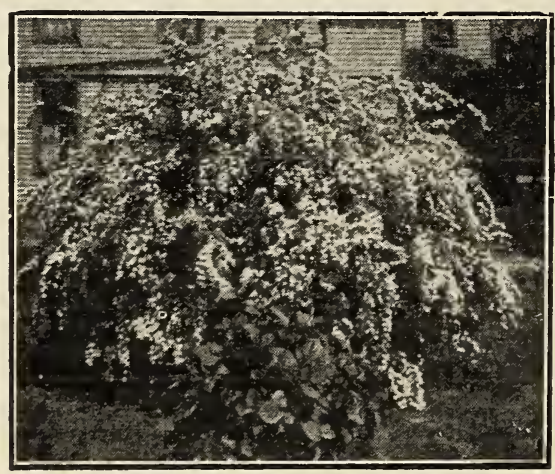

Spirea Van Houttei

SPIREA, VAN HOUTTEI-Graceful, with long, drooping sprays, thickly studded with handsome, pure white flowers; hence its popular name, "Bridal Wreath." The finest Spirea of them all. 2 to 3 feet, 60c; Per Doz. $\$ 6.00$ SYRINGA (Mock Orange)-Beautiful, tall, vigorous, hardy, with profuse, white, orange-like flowers in May. Very popular. 2 to 3 feet, each.................................................75e

WEIGELIA ROSEA-Hardy, with profuse, rosy, trumpet shaped flowers in May. The most superb shrub of the season. Each...............................................................................75c

WEIGELIA, EVA RATHKE-Flowers a brilliant crimson; a beautiful, clear, distinct shade. Each...................750 


\section{Vines}

Ornamentals of this class are so hardy and so beatiful that they deserve greater attention than they receire. No artist can produce pictures equal to the wealth of beauty displayed by the elegant Wistaria, the graceful Honeysuckle, or the charming and magnificent clematis when in the glory of full bloom.

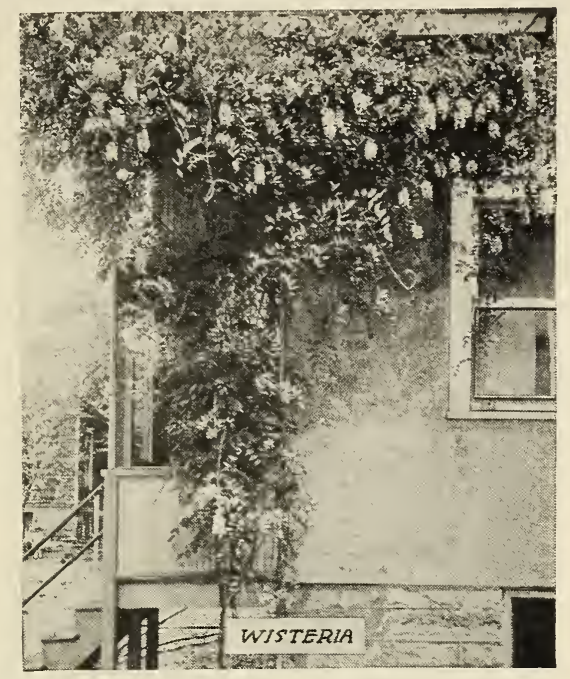

AMPELOPSIS (Veitchii or Boston Ivy)-Leaves a little smaller and more ivy like in form than the foregoing. Overlapping each other they form a dense sheet of green. The plant requires a little protection the first winter until it is established. Each.

$.75 \mathrm{c}$

ARISTOLOCHIA (Dutchman's Pipe)-A native species of climbing habit and rapid growth, light green foliage, and pipe-shaped yellowish brown flowers. Each............75c

BIGNONIA (Scarlet Trumpet Flower)-A splendid climber, vigorous and hardy, with clusters of large trumpet-shaped scarlet flowers in August. Each.........................75c

CLEMATIS-The different varieties and species of Clematis now in cultivation are of the highest beauty and utility. They vary greatly in their foliage and flowers and are adapted to various uses.

CLEMATIS, JACKMANI-A very profuse blooming variety with flowers from four to six inches in diameter, of an intense violet-purple color borne successionally in continuous masses on the summer shoots. The very best sort for general planting. Each. $\$ 1.00$

CLEMATIS, HENRYI-Fine bloomer; flowers large, of a beautiful creamy white, consisting generally of from six to eight sepals. June to October. Each.....................\$1.00

CLEMATIS MADAME EDOUARD ANDRE-Flowers large, of a beautiful bright velvety red, very free flowering and continuous bloomer. Each.......................................\$1.00

CLEMATIS PANICULATA-A great novelty. One of the most desirable, useful and beautiful of hardy garden vines, a luxuriant grower, profuse bloomer with fine foliage. Flowers of medium size, very pretty and fragrant, produced in the greatest profusion in late summer. Ea. 75c

HONEYSCCKLE (Monthly Fragrant)-Blooms all summer; very sweet. Each

HONEYSUCKLE (Hall's Japan)-A strong, vigorous, evergreen variety with pure white flowers changing to yellow. Very fragrant; covered with flowers from June to Norember. Better have some winter protection. Ea. 75e HONEYSUCKLE SCARLET TRUMPET-One of the handsomest in cultivation; a strong, rapid grower; flowers a bright scarlet, not much odor. Each........................75e

IVISTARIA (Purple)-A most beautiful climber of rapid growth, producing long, pendulous clusters of pale blue flowers. When well established makes an enormous growth. It is very hardy and one of the most superb vines ever introduced. 


\section{Hardy Herbaceous Perennials}

DAHLIAS-Well known autumn flowering plants, growing from two to five feet high, and producing a profusion of flowers of the most perfect and beautiful form, varying in color from the purest white to the darkest maroon.

GOLDEN GLOW-We call attention to this notable novelty, and offer it as the finest herbaceous border plant introduced for many years. It is of easy growth and is giving complete satisfaction. But few plants can vie with it in attractiveness. There is no floral novelty before the public to be compared to it for effectiveness and worth.

PEONIES-No flowers exceed the Peonies in popularity, and none are more easily grown. They are seldom attacked by insects or disease, and are perfectly hardy, requiring no covering in the severest weather. They thrive in all kinds of soil and flourish in a rich deep loam.

No hardy perennial is of more permanent value than the Peony. The first cost is the only cost, and they continue to increase in size and value for many years. The foliage is rich and beautiful deep green color, which renders the plant very ornamental even when out of flower, and no other flowers are so well adapted for interior decoration and none make more massive color effect when planted in a border or in a bed on the lawn. Their popularity has increased during the past few years since the new improved varieties have been disseminated. Peonies range in color from cream and pure white through the various shades of pink and red to the deepest purple and maroon, in all possible combinations of tint and form.

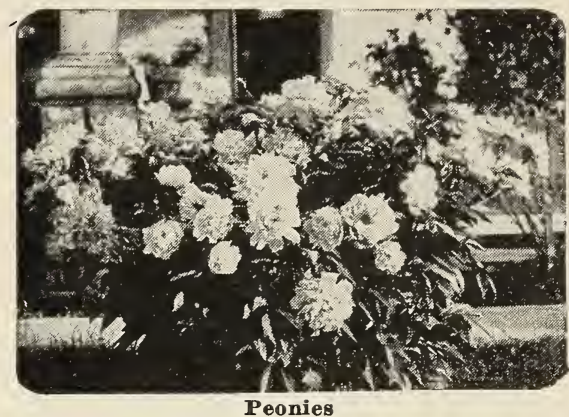

THE VERY BEST PEONIES

DUCHESS DE NEMOURS-White with sulphur yellow center. Mid-season. Each 75c.

EDULIS SUPERBA-Bright, clear pink. Large bloom. Very early. Each 75c.

LOUIS VAN HOUTTE-Deep carmine rose. Very brilliant. Late. Each 75c.

FESTIVA MAXIMA-White sometimes flecked crimson. The best. Early. Each 75.

ALEXANDRE DUMAS-Brilliant pink. Fragrant. Midseason. Each 75c.

COMTE H. DE CHOESSEL-Dark red. Very fine Season late. Each 75c.

LA TULIPE-Variegated white and pink. A beautiful peony. Mid-season. Each 75c.

RUBRA SUPERBA-Rich, deep crimson, nearly black. Large. Very late. Each \$1.00.

CLAIRE DUBoIS-Clear violet rose, tipped white. Season late. Each \$1.00.

FRINGE LEAF-Bright red. Very early. Each \$1.50. ASA GRAY-Pale lilac pink. Midseason. 75c each.

FELIX CROUSSE-Very brilliant red. \$1.00 each.

MME. DE VERNEVILLE-P ure white, early. \$1.00 each. OFFICINALIS RUBRA-Bright crimson. Very early. $\$ 1.00$ each.

SYDONIE-Lilac pink. Early. \$1.00 each.

YUCCA FILAMENTOSA (Adam's Needle) - Threadleaved, creamy white; stem three to four feet high, covered with bell-shaped flower, on laterals forming a pyramid; very striking. Price each

LILY OF THE VALLEY-This lily is as hardy as any plant can possibly be, and when planted in open ground will increase pretty rapidly. Price, each...............................45c 
THE BEST GERMAN IRIS

Price each 20c; Per Dozen \$1.75

FLORENTINA-White with tinge of lilac. Very fragrant. GERTRUDF-Rare violet blue.

IIARLEQUIN-Pure white flecked with lavender and royal purple.

HONORABILIS-Bright golden yellow veined with crimson and maroon.

L'AVENIER-Beautiful shade of light lavender.

MADAME CHEREAU-Clear white frilled about the edge with violet.

MRS. H. DARWIN-White, laced with maroon, violet at the base.

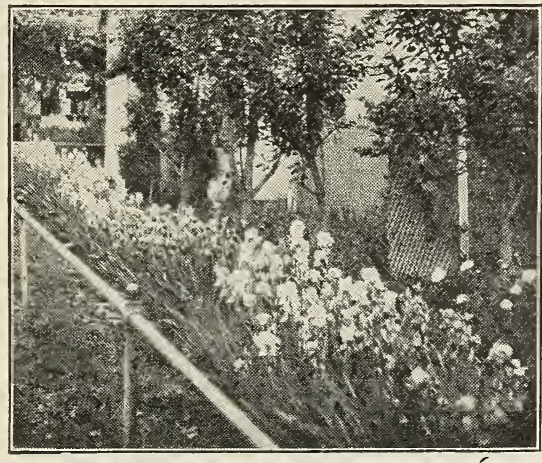

Hedge of Iris

THE BEST HARDY PHLOX

Price each, 35c; Per Dozen $\$ 3.50$

AMERICAN BEAUTY-Delicate pink with silvery reflex. ATHIS-Clear salmon.

ECLAIREUER-Bright purplish rose, with light center.

MRS. JENKINS-Very large, fine, pure white.

PANTHEON-Bright crimson.

RICHARD WALLACE-White, with bright pink eye.

\section{Floral Bulbs}

(Floral Bulbs for Spring Planting only)

\section{GLADIOLI}

Price Mixed, each 10c; per doz. \$0.75

Price Named, each 10c; per doz. $\$ 1.00$

GLADIOLI-Of all our summer flowering bulbs gladioli stand at the head of the most varied and beautiful class. The flowers are produced in spikes two feet in height and upwards; the brilliant scarlet and crimson of some form a striking contrast with the delicate shades and penciling of the lighter colored varieties. By planting at intervals from May 1st to middle of June a succession of flowers can be had from July to October.

AMERICA-Beautiful dainty pink.

BARON JOSEF HULOT-Deep, violet blue.

EMPRESS OF INDIA-Rich, dark red.

MRS. FRANCIS KING-Briliant scarlet.

PEACE-Pure white with pale violet feathering on interior petals.

SCHWABEN-Sulphur yellow, dark blotch in center.

\section{Hedge Plants}

BARBERRY (B. Thunbergii)-A low, spreading bush, with small branches covered with small sharp thorns and in spring with small yellow flowers, succeeded by bright scarlet berries; foliage changes in the autumn to shades of scarlet and gold; makes a dense, thick hedge.

Price, 12 to 18 inches...............Per 10,\$3.50; Per 100, \$25.00 PRIVET (Amoor River North)-This is the most beautiful hedge plant grown. It has a luxuriant, glossy leafage and thick clusters of fragrant white flowers. Hardy, free-growing, of dense, neat habit, attractive all the year, in berry leaf, or flower. Makes a beautiful specimen plant, a fine screen, group or hedge.

Price, 18 to 24 inches...

Per $100, \$ 20.00$

Price, 12 to 18 inches ...Per 100,\$15.00 


\section{Trees}

The stock of ornamental trees that we offer will be found to comprise a sufficient number of kinds that are really valuable, so that our customers may, from the list offered, secure such a variety as will give full satisfaction. For Streets, Roads and Vide Avenues-American Elm, Sugar and Silver Maple, Carolina Poplar.

For Driveways through Lawns and Parks-Norway Maple, Tulip Tree, Catalpa, American Linden.

Single Specimens of Large Growth to be Branched from the Ground-Birches, particularly Cut-Leaf Weeping. Austrian and Scotch Pines, Norway and Colorado Spruces, Balsam Fir.

Single Specimens of Medium Growth to be Branched from the ground-Prunus Pisardii, Hemlocks, White Pine, Arbor Vitae.

Strong Growing Trees of Pyramidal Habit-Carolina Poplar, Balsam Fir, Pyramidalis Arbor Vitae.

Trees that Thrive in Moist Locations-American Elm, American Linden, Ash, Catalpas, Poplars and Willows.

Trees that Thrive on Dry Knolls or Poor Soils-Silver Leaf Maples and Poplars.

Best Trees for Windbreaks-Erergreens, Norway Spruce and White Pine.

Flowering Trees-Judas Tree, Fringe Tree, White and Purple Lindens, Horse Chestnut, Catalpas.

Cut-Leaf-Cut-Leaf Weeping Birch, Weirs Cut-Leaf Maple.

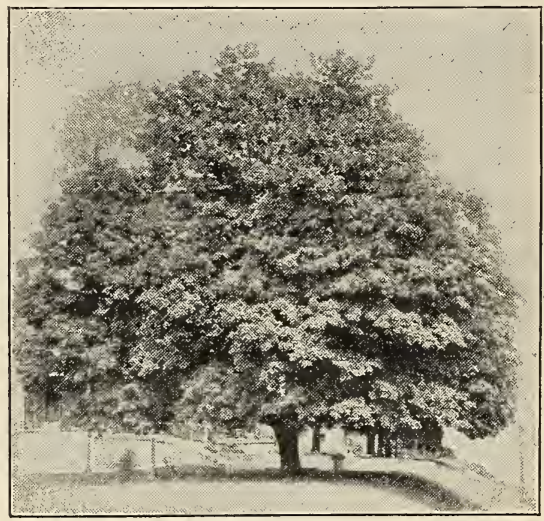

Sugar Maple

ASH WHITE-Rapid growing tree, of fine symmetrical outline. A valuable street or park tree and should be extensively planted.

Price, 6 to 8 feet.......................... $\$ 1.00 ; 8$ to 10 feet, \$1.50

BIRCH, WHITE-A beautiful native tree particularly in the northern part of the country. Its shining white bark and slender, dark brown branches make it a conspicuous and very attractive object. Foliage large and handsome.

Price, 5 to 6 feet...........................ech $\$ 1.50 ; 6$ to 8 feet, $\$ 2.50$

CAROLINA POPLAR-Takes front rank among best of poplars; it is one of the most rapid growers among shade trees. Its branches spread just enough to give it a symmetrical appearance. It has advantages over other shade trees because it will grow on any kind of soil, swampy or mucky, light or heavy. Its roots penetrate the hardest soil, it withstands all hardships and thrives in places where others fail to live. It is easily started and gives shade in a short time. Its leaves are large and stay green till quite late in the fall.

Price, 6 to 8 feet........................... 75c; 8 to 10 feet, $\$ 1.00$

CATALPA BUNGEI-A remarkable species forming a dense, round umbrella-like head; makes a beautiful lawn tree when grafted or budded on a high stem.

Price, 2-year head, 5 to 6 feet....Fach $\$ 3.00 ; 6$ to $8 \mathrm{ft}$. $\$ 4.00$

CATALPA SPECIOSA-A variety which is said to have originated in the West; it is very hardy and a rapid grower and is being extensively planted for commercial purposes; has broad deep green leaves and beautiful large blossoms, making it a highly ornamental tree for lawn or street. Valuable for planting in groves for growing poles, posts and rallroad ties.

Price, 6 to 8 feet.........................ech $\$ 1.00 ; 8$ to 10 feet, $\$ 1.50$ 


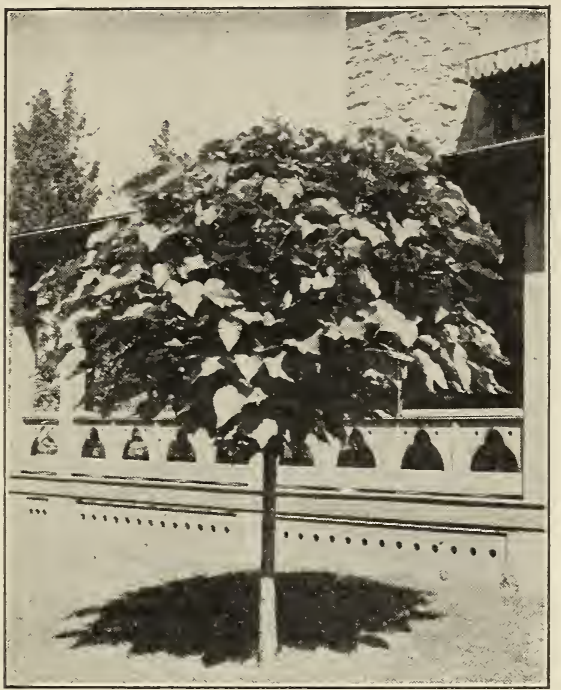

\section{Catalpa Bungei}

CHESTNUT, AMERICAN SWEET-Well known beautiful tree, valuable for fruit and timber. Should be planted only on thin, dry soils.

CRAB (Bechtel's Double Flowering)-This blooms in early spring exhaling a most delightful fragrance from its masses of double, delicate pink flowers.

Price 3 to 4 feet. Each.............................................................\$1.50

ELM, AMERICAN WHITE-The noble, spreading, drooping tree of our woods. One of the grandest of park or shade trees.

Price, 6 to 8 feet.

Each, $\$ 1.00 ; 8$ to 10 feet, $\$ 1.50$

HACKBERRY or NETTLE TREE-A highly ornamental tree, somewhat similar to the elm but more formal. The ripe fruit is a joy to boys and birds in the fall and early winter. Used somewhat as a street tree, but not half appreciated. Price, 6 to 8 feet. Each................................\$1.50

HORSE CHESTNUT-Common or white, flowering. A very beautiful, well known tree, with round, dense head, dark green foliage, and an abundance of showy flowers in early spring.

Price, 6 to 8 feet. Each $\$ 2.50$

LINDEN (American or Lime)-A rapid growing, large, beautiful native tree. Flowers very fragrant.

Price, 6 to 8 feet........................Each $\$ 2.00 ; 8$ to 10 feet, $\$ 3.50$ MAPLE (Silver Leaved)-Leaves white underneath: of rapid growth; very ornamental and one of the best street trees we have. 6 to $8 \mathrm{ft}$. $\$ 1.00$ each; 8 to $10 \mathrm{ft}$. $\$ 1.50$ each.

NORWAY MAPLE-Of spreading, rounded form; foliage large, dark green; a rich and majestic shade tree.

Price, 6 to 8 feet.............................. $\$ 3.00 ; 8$ to 10 feet, $\$ 4.00$ SUGAR MAPLE-A beautiful, stately tree of fine form; a desirable shade tree. Slow grower.

Price 6 to 8 feet, $\$ 2.00$ each; 8 to 10 feet, $\$ 3.00$ each.

SYCAMORE AMERICAN Or PLANE TREE-A wellknown tree, very common throughout the United States; leaves heart-shaped at base, the short lobes sharp pointed; branches are wide spreading.

Price, 6 to 8 feet............................... $\$ 1.50 ; 8$ to 10 feet, $\$ 2.50$

SYCAMORE ORIENTAL PLANE OY EUROPEAN (P. Orientalis) - A rapid growing, erect tree with bright green foliage; much more esteemed than the American variety as a shade tree; very desirable for parks, streets and lawns. Price 6 to 8 feet, $\$ 1.50$ each; 8 to 10 feet, $\$ 2.50$.

WALNUT BLACK-Valuable for nuts and timber. It is hardy and succeeds best on a rich, deep moist soil. Too well known for long description.

Price, 6 to 8 feet. Each 750

\section{WEEPING VARIETIES}

BIRCH (Cut-Leaf Weeping)-Erect, stately, rapid growing tree, with long, slender, pendant branches, delicately cut leares and silvery white trunk; especially fine when near evergreens; hardy; the most elegant weeping tree ou the list. 


\section{Evergreens}

In handling and planting evergreens never allow the roots to become dry for an instant. Their juices are resinous, and when once dry, water has no power to restore them; dip the roots in "grout" or very thin mud, and plant quickly; cover the roots with fresh soil and with a heavy piece of wood beat the earth solid over them. Fill up and pound again, and finish by bringing fresh loose earth about the tree with a hoe. No wind can now bend the tree about so as to break the tender rootlets as fast as formed.

Use Scotch Pine, White Spruce, Norway Spruce, and White Pine for high screens and Arbor Vitae or Red Cedar for low ones.

ARBOR VITAE (American)-This plant is, all things considered, the finest evergreen for hedges. It is very hardy and easily transplanted, few plants failing if properly handled. It grows rapidly and with little care, or rather by easy management, it soon forms a most beautiful hedge, very dense and perfectly impervious to the sight. It is never planted to turn stock, but it forms a most desirable and ornamental screen to divide the lawn from other grounds.

Price, 2 to $3 \mathrm{ft}$. Each, 75 c; 18 to 24 inches, per 100, $\$ 45.00$ 12 to 18 inches, per 100, \$35.00.

ARBOR VITAE (Pyramidalis)-Superb, new and hardy sort, of very compact habit; much better than the Irish Juniper and grown in a perfect column. Largely planted in cemeteries, owing to the small amount of space it occupies. This is perhaps the most valuable. Arbor Vitae in cultivation. Price, 2 to 3 feet, $\$ 3.00$.

NORWAY SPRUCE-A lofty, elegant tree of perfect pyramidal habit, exceedingly picturesque and beautiful. One of the best evergreens for windbreaks.

Price, 18 to 24 inches........................................... 100, \$30.00 Price, 12 to 18 inches.................................................. 100, 25.00

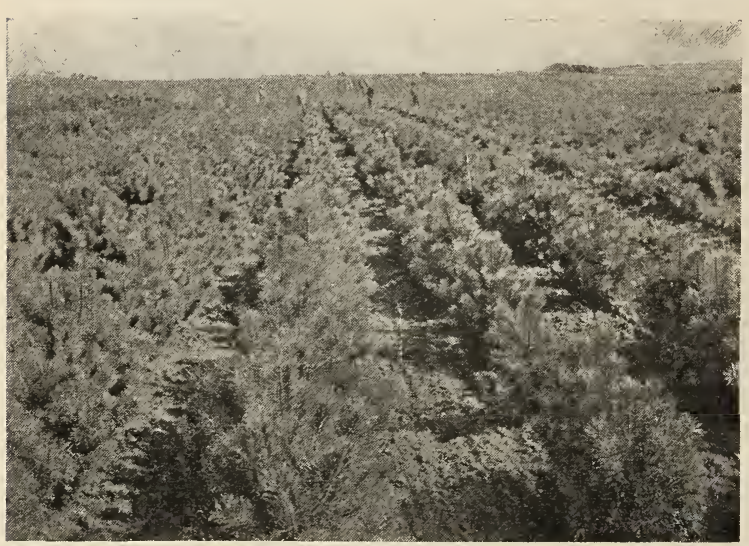

How We Grow White Pine

PINE, WHITE-One of the best evergreens. The foliage is a warm, light green, often with a bluish tinge. The leaves, in fives, are three or four inches long, soft and delicately fragrant. It does not grow as rapidly the first few years as some, but after being planted six or eight years it is the most rapid grower of all our evergreens. Price, 18 to 21 inches, per 100, \$30.00; 12 to 18 inches, per $100, \$ 25.00$.

SPRUCE, COLORADO BLUE-This species has been tested at various points on the prairies of the West and Northwest with perfect success, and during a temperature of $30^{\circ}$ below zero, in exposed situations, entirely uninjured. One of the hardiest evergreens and the most beautiful in color and outline. "This is the king of spruces, clothed in royal robes of silver and sapphire, a very Kohinoor among the gems of the Rockies."

Price, 2 to 3 feet $\$ \$ .00$

Price, 18 to 24 inches

Our evergreens are given special care, handled carefully and transplanted frequently, so there is no danger in moving them from our nurseries. 